\title{
Introduction to Computing
}




\section{Introduction to Computing Percy Mett \\ Department of Computing The Open University}

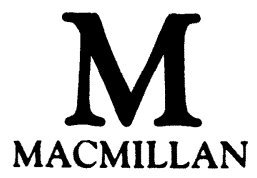


(C) Percy Mett 1990

All rights reserved. No reproduction, copy or transmission of this publication may be made without written permission.

No paragraph of this publication may be reproduced, copied or transmitted save with written permission or in accordance with the provision of the Copyright, Designs and Patents Act 1988, or under the terms of any licence permitting limited copying issued by the Copyright Licensing Agency, 33-4 Alfred Place, London WC1E 7DP.

Any person who does any unauthorised act in relation to this publication may be liable to criminal prosecution and civil claims for damages.

First published 1990

Published by

MACMILLAN EDUCATION LTD

Houndmills, Basingstoke, Hampshire RG21 2XS

and London

Companies and representatives

throughout the world

\section{British Library Cataloguing in Publication Data}

Mett, Percy

Introduction to computing.

1. Computer systems

I. Title

004

ISBN 978-0-333-39336-9 ISBN 978-1-349-08039-7 (eBook)

DOI 10.1007/978-1-349-08039-7

Lotus 1-2-3 is a trademark of Lotus Development Corporation.

UNIX is a trademark of AT\&T Bell Laboratories.

MicroSoft Word is a trademark of MicroSoft Corporation.

VAX is a trademark of Digital Equipment Corporation.

CP/M is a trademark of Digital Research Inc. 


\section{Contents}

Preface xii

Acknowledgements $\quad x v$

1 Information Processing-Why and How? 1

1.1 Two Examples $\quad 2$

An airline booking system $\quad 2$

Banking systems $\quad 3$

$\begin{array}{ll}1.2 \text { Computerisation } & 5\end{array}$

1.3 Problem Analysis 5

$\begin{array}{ll}\text { Specification } & 7\end{array}$

$\begin{array}{lr}\text { Top-down design } & 8\end{array}$

$\begin{array}{lr}\text { Stepwise refinement } & 8\end{array}$

$\begin{array}{lr}\text { Structure trees } & 10\end{array}$

1.4 Algorithms and Data 11

$\begin{array}{lr}\text { The stored program } & 12\end{array}$

$\begin{array}{ll}\text { Data } & 12 \\ & 12\end{array}$

Atomic data types $\quad 13$

$\begin{array}{lr}\text { Variables } & 14\end{array}$

Arrays $\quad 15$

1.5 Library Routines 16

$\begin{array}{ll}\text { Parameters } & 16\end{array}$

$\begin{array}{ll}\text { Input and output } & 17\end{array}$

$\begin{array}{ll}\text { Summary of Chapter } 1 & 17\end{array}$

2 Program Control $\quad 20$

2.1 Control Structures $\quad 21$

$\begin{array}{ll}\text { Loop constructs } & 21\end{array}$

Conditional loops $\quad 23$

Branch constructs $\quad 25$

$\begin{array}{ll}2.2 \text { Assignment } & 27\end{array}$

Input and output $\quad 28$

Controlled loops $\quad 30$

Searching an array $\quad 31$

2.3 Modular Design $\quad 32$

$\begin{array}{ll}\text { Modules } & 34\end{array}$ 
2.4 Nested Control Structures $\quad 35$

Two-dimensional arrays $\quad 35$

$\begin{array}{ll}\text { Summary of Chapter } 2 & 37\end{array}$

3 High-level Programming 43

3.1 Writing Readable Programs $\quad 45$

Choosing identifiers $\quad 46$

Data tabulation $\quad 47$

$\begin{array}{ll}\text { Enumerated types } & 49\end{array}$

Data declaration $\quad 50$

Self-documentation $\quad 50$

Constants $\quad 51$

3.2 Statements $\quad 53$

Simple statements $\quad 53$

Updating a variable $\quad 55$

Repetitive statements $\quad 56$

If statements $\quad 60$

$\begin{array}{ll}\text { Case statements } & 61\end{array}$

3.3 Expressions 63

Algebraic expressions $\quad 64$

$\begin{array}{ll}\text { String expressions } & 65\end{array}$

Boolean expressions $\quad 66$

$\begin{array}{ll}3.4 \text { Subprograms } & 68\end{array}$

$\begin{array}{lr}\text { Procedures } & 68\end{array}$

$\begin{array}{lr}\text { Functions } & 72\end{array}$

Block structure $\quad 76$

3.5 Execution of Subprograms

$\begin{array}{ll}\text { Flow of control } & 77\end{array}$

$\begin{array}{ll}\text { Dynamic structure } & 78\end{array}$

$\begin{array}{ll}\text { Parameter-passing mechanisms } & 78\end{array}$

The stack model $\quad 80$

$\begin{array}{ll}3.6 \text { Searching } & 82\end{array}$

$\begin{array}{ll}\text { Linear search } & 82\end{array}$

Binary search $\quad 85$

$\begin{array}{ll}\text { 3.7 Sorting and Merging } & 87\end{array}$

$\begin{array}{ll}\text { Selection sort } & 87\end{array}$

$\begin{array}{ll}\text { Merging } & 89\end{array}$

$\begin{array}{ll}\text { Merge sort } & 90\end{array}$

Summary of Chapter $3 \quad 91$

4 Program Development Issues 99

4.1 The Software Life-cycle $\quad 99$

$\begin{array}{lr}\text { Systems development } & 100\end{array}$

$\begin{array}{ll}\text { Formal methods } & 101\end{array}$

$\begin{array}{ll}\text { Software design } & 101\end{array}$

$\begin{array}{ll}\text { Choice of language } & 102\end{array}$

$\begin{array}{ll}\text { Verifying the program } & 104\end{array}$ 
Contents vii

$\begin{array}{ll}\text { Efficiency } & 106\end{array}$

$\begin{array}{ll}\text { Maintenance } & 108\end{array}$

4.2 Program Testing 108

$\begin{array}{ll}\text { Error diagnosis } & 109\end{array}$

$\begin{array}{lr}\text { Test data } & 110\end{array}$

4.3 Exception Handling $\quad 111$

Summary of Chapter $4 \quad 113$

5 Hardware $\quad 117$

5.1 The Main Processor 118

$\begin{array}{ll}\text { von Neumann architecture } & 119\end{array}$

Lines of communication $\quad 119$

Storage elements $\quad 120$

$\begin{array}{ll}\text { Registers } & 121\end{array}$

5.2 How the Processor Works 123

$\begin{array}{ll}\text { The fetch-execute cycle } & 123\end{array}$

$\begin{array}{lr}\text { Servicing interrupts } & 125\end{array}$

$\begin{array}{ll}\text { Microcode } & 125\end{array}$

Machine instructions $\quad 126$

$\begin{array}{lr}\text { Stack processors } & 127\end{array}$

$\begin{array}{ll}5.3 \text { Memory } & 128\end{array}$

Immediate access store $\quad 128$

Machine code $\quad 131$

Cache memory $\quad 132$

Backing storage $\quad 133$

5.4 Peripheral Operation $\quad 134$

$\begin{array}{ll}\text { Processor-controlled input/output } & 134\end{array}$

Direct memory access $\quad 135$

$\begin{array}{ll}\text { Interfacing } & 136\end{array}$

Interrupt priorities $\quad 137$

$\begin{array}{ll}5.5 \text { Logic Circuits } & 137\end{array}$

Logic gates 137

$\begin{array}{ll}\text { Truth tables } & 138\end{array}$

$\begin{array}{ll}\text { Boolean algebra } & 139\end{array}$

$\begin{array}{ll}\text { Design and simplification of circuits } & 141\end{array}$

The NAND gate $\quad 143$

5.6 Keyboards, Screens and Printers $\quad 146$

$\begin{array}{ll}\text { Visual display units } & 146\end{array}$

$\begin{array}{ll}\text { Printers } & 148\end{array}$

Microfiche and microfilm $\quad 151$

5.7 Specialised Input and Output Devices 152

Document readers $\quad 152$

Digitisation 154

Graphics devices $\quad 155$

Speech devices 156

$\begin{array}{lr}\text { Other forms of input/output } & 156\end{array}$

$\begin{array}{lr}\text { Summary of Chapter } 5 & 157\end{array}$ 
6 Low-level Programming 163

6.1 Binary Representation of Data 164

$\begin{array}{ll}\text { Bit patterns for characters } & 164\end{array}$

$\begin{array}{ll}\text { Hexadecimal code } & 165\end{array}$

$\begin{array}{ll}\text { Binary coded decimal } & 167\end{array}$

$\begin{array}{ll}\text { Binary numbers } & 168\end{array}$

6.2 Binary Arithmetic in a Fixed-length Store $\quad 170$

$\begin{array}{ll}\text { Negative numbers } & 170\end{array}$

$\begin{array}{ll}\text { Signed magnitude } & 170\end{array}$

Ones' complement 171

Twos' complement $\quad 172$

$\begin{array}{lr}\text { Multiplication } & 174\end{array}$

$\begin{array}{ll}\text { 6.3 Floating-point Numbers } & 175\end{array}$

$\begin{array}{ll}\text { Mantissa and exponent } & 175\end{array}$

$\begin{array}{ll}\text { Range and accuracy } & 176\end{array}$

$\begin{array}{ll}\text { Loss of accuracy } & 177\end{array}$

$\begin{array}{ll}\text { Floating-point arithmetic } & 178\end{array}$

6.4 Assembly Coding $\quad 179$

$\begin{array}{ll}\text { Mnemonic operation codes } & 179\end{array}$

$\begin{array}{lr}\text { Addressing modes } & 180\end{array}$

$\begin{array}{ll}\text { Symbolic addressing } & 181\end{array}$

$\begin{array}{ll}\text { Code assembly } & 181\end{array}$

A two-pass assembler $\quad 182$

$\begin{array}{lc}\text { Data addresses } & 183\end{array}$

$\begin{array}{ll}\text { Macros and subroutines } & 184\end{array}$

$\begin{array}{ll}\text { 6.5 Address Modification } & 186\end{array}$

$\begin{array}{ll}\text { Indirect addressing } & 186\end{array}$

$\begin{array}{lc}\text { Indexed addressing } & 188\end{array}$

$\begin{array}{ll}\text { Machine-code representation } & 191\end{array}$

$\begin{array}{ll}\text { Summary of Chapter } 6 & 191\end{array}$

7 All About Data 199

7.1 Data Capture $\quad 199$

Data collection $\quad 201$

$\begin{array}{ll}\text { Verification } & 203\end{array}$

7.2 Data Validation 203

Range checks $\quad 203$

$\begin{array}{ll}\text { Encoding data } & 204\end{array}$

$\begin{array}{ll}\text { Check digits } & 204\end{array}$

Control totals $\quad 206$

$\begin{array}{ll}\text { 7.3 Structured Data } & 207\end{array}$

$\begin{array}{ll}\text { A library catalogue } & 207\end{array}$

$\begin{array}{ll}\text { Records } & 208\end{array}$

Records and arrays $\quad 211$

$\begin{array}{ll}\text { Tables of data } & 211\end{array}$

Summary of Chapter $7 \quad 213$ 
Contents ix

8 Files $\quad 217$

$\begin{array}{ll}\text { 8.1 Serial Processing } & 217\end{array}$

Magnetic tape $\quad 218$

Microcomputer tapes $\quad 221$

Batch processing $\quad 222$

A sequential file update $\quad 223$

8.2 Direct-access Devices 225

Magnetic disc storage $\quad 225$

$\begin{array}{ll}\text { Winchester discs } & 228\end{array}$

Floppy-disc drives $\quad 228$

Magnetic drums $\quad 230$

Security of data $\quad 230$

8.3 File Handling 231

File operations $\quad 232$

How a channel works $\quad 234$

Random-access files $\quad 236$

$\begin{array}{ll}\text { Structured files } & 237\end{array}$

8.4 File Organisation 238

Random files $\quad 239$

Indexed files $\quad 239$

Indexed sequential files $\quad 241$

8.5 Information Retrieval 243

Inverted files $\quad 243$

Databases 244

8.6 The Filing System $\quad 247$

$\begin{array}{ll}\text { Directories } & 247\end{array}$

File sharing $\quad 248$

Summary of Chapter $8 \quad 249$

9 Dynamic Data Structures

\begin{tabular}{ll}
9.1 Lists & 255 \\
\hline & 256
\end{tabular}

Abstract lists $\quad 256$

Pointers and cursors $\quad 258$

9.2 Stacks 259

An amazing problem $\quad 262$

9.3 Queues $\quad 263$

Modelling a queue $\quad 263$

$\begin{array}{ll}9.4 \text { Trees } & 264\end{array}$

$\begin{array}{ll}\text { Sort trees } & 267\end{array}$

$\begin{array}{ll}\text { Searching a sort tree } & 270\end{array}$

$\begin{array}{ll}\text { Summary of Chapter } 9 & 270\end{array}$

10 Systems Software $\quad 275$

$\begin{array}{ll}\text { 10.1 Software and Firmware } & 275\end{array}$

$\begin{array}{ll}\text { Applications software } & 276\end{array}$

$\begin{array}{ll}\text { 10.2 High-level Language Support } & 277\end{array}$

$\begin{array}{ll}\text { The translation process } & 277\end{array}$ 
10.3 Syntax of Programming Languages $\quad 280$

$\begin{array}{ll}\text { Defining syntax rules } & 281\end{array}$

Expression analysis $\quad 283$

Reverse Polish notation $\quad 285$

The evaluation stack $\quad 286$

Unary operators $\quad 287$

10.4 Code Generation $\quad 288$

Assemblers $\quad 290$

$\begin{array}{ll}\text { 10.5 Utility Programs } & 291\end{array}$

File utilities $\quad 291$

Editors $\quad 292$

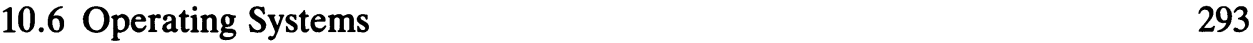

$\begin{array}{ll}\text { The nucleus } & 294\end{array}$

Interrupt handling $\quad 294$

Multiprogramming $\quad 296$

Real-time processing $\quad 298$

$\begin{array}{ll}10.7 \text { Memory Management } & 300\end{array}$

$\begin{array}{ll}10.8 \text { Black Boxes } & 302\end{array}$

The Acorn BBC $\quad 304$

Summary of Chapter $10 \quad 305$

11 How to Communicate $\quad 313$

11.1 Human-computer Dialogue $\quad 313$

$\begin{array}{lr}\text { Prompting for input } & 314\end{array}$

$\begin{array}{ll}\text { Menus } & 316\end{array}$

$\begin{array}{ll}\text { Form filling } & 318\end{array}$

Free-format dialogue $\quad 318$

$\begin{array}{ll}\text { Graphics } & 319\end{array}$

Displaying information $\quad 322$

11.2 Remote Access 323

Special-purpose terminals $\quad 323$

$\begin{array}{ll}\text { Modems } & 324\end{array}$

11.3 Intercomputer Communication $\quad 326$

$\begin{array}{ll}\text { Networking } & 327\end{array}$

Wide-area networks $\quad 329$

Summary of Chapter $11 \quad 330$

12 Computing Today 333

12.1 The Growth of Computing 333

The electronic office $\quad 334$

Electronic publishing $\quad 336$

Information retrieval $\quad 336$

Teletext and viewdata $\quad 338$

Process control $\quad 339$

$\begin{array}{ll}\text { Scientific calculations } & 340\end{array}$

$\begin{array}{ll}\text { Computer-aided design } & 341\end{array}$

Education 
12.2 The Age of Information Processing 344

Social effect of computers 344

Computer crime $\quad 345$

The computer straitjacket 346

$\begin{array}{ll}12.3 \text { Privacy of Information } & 347\end{array}$

Laws of privacy 348

Security of data 349

12.4 Developing Applications 350

Expert systems 351

Robotics 351

Is it worth while? 351

Summary of Chapter 12

Appendix A: ASCII codes 357

Appendix B: Other BASICs $\quad 359$

Appendix C: Coursework and projects 363

Appendix D: Hints for the solution of selected Further exercises 365

$\begin{array}{ll}\text { Glossary } & 372\end{array}$

Bibliography $\quad 384$

$\begin{array}{ll}\text { Index } & 385\end{array}$ 


\section{Preface}

This is a book, not about computers, but about computing - the science of using the computer. The study of computing as a science in schools and colleges has grown dramatically in recent years. From a position as a Cinderella subject on the periphery of the curriculum, it has developed into a mainstream area of study examined by all the public examining bodies both in the GCSE and in the Advanced Level GCE examinations. The increase in the number of candidates taking the subject has not been matched by up-to-date textbooks to provide adequate instruction in the subject. It is the aim of this book to fill this void by providing a main text which gives a broad coverage of the new Advanced level syllabuses.

Despite a massive increase in popularity among candidates, A-levels in Computing fail to command a positive image. Universities and Polytechnics continue to prefer candidates with traditional A-levels for admission to degree courses in Computer Science, rather than those with A-levels in Computing. The reason is not hard to find. The emphasis in A-level courses has been on the wrong topics and the wrong methods. The Alvey Report stated (page 62): "Universities in fact are having to give remedial education to entrants with A-level computer science. Uncorrected, the explosion in home computing with its 1950 s and 60s programming style will make this problem even worse."

The new syllabuses which the GCE Boards introduced in the mid-1980s have gone some way towards redressing the balance. However, the main improvement will come from the use of proper design methods in the development of software. This important message is put across in the first four chapters of this book. Software development-including design-is still a much neglected topic in the teaching of the subject, and early exposure is required to ensure that students appreciate its importance. Left to their own devices, students are quick to acquire bad programming habits; it is preferable to inculcate in them the correct techniques at the earliest possible stage.

Hardware topics are not introduced until later on. Those used to earlier textbooks on Computing may find this approach unusual. However, the subject is Computing rather than Computers-our interest in computers stems only from their role in Computing.

The A-level syllabuses do not presuppose any previous knowledge of the subject. This book aims to be intelligible as a first course in Computing. It does not, however, teach any programming language as such. This has to be covered by a parallel course, using a language that is locally available. 
The first three chapters introduce the use of program control structures as design tools. The method of top-down stepwise refinement is taught with the aid of structure diagrams, followed by a more general look at software design and program development in chapter 4. These topics include program correctness, maintainability and efficiency. The operation of the hardware, including peripheral devices, is discussed in chapter 5 . The function of the hardware is specified in terms of its machine instruction set; this is most easily taught by way of assembly language, in chapter 6 . Binary arithmetic is left until this point, as its main relevance is at this level of the computer hierarchy.

The organisation of data is an important topic which spans chapters 7 to 9 . The methods used to access data have been influenced by the choice of storage media available. A continuous thread is woven through the hardware and software aspects so as to present a coherent picture. Operating systems and other systems software which, together with the hardware, make up the complex machine described indiscriminately as a computer, form the subject matter for chapter 10 .

In chapter 11 we discuss communication, at both the human-computer and the computer-computer levels. This discussion includes a brief introduction to networks. The final chapter looks at some of the ways in which the computer is currently put to use and the social issues raised thereby.

Readers familiar with traditional texts will notice a complete absence of that so-called programming tool, the flowchart. I make no apology for its omission. Far from aiding program design, flowcharts hamper it, forcing the programmer to think in terms of the computing device and not the problem. A more useful design tool, the structure tree, is introduced early on to aid high-level programming. Flowcharts have their uses in the documentation of complex programs, but these are beyond the scope of this book.

No single text can hope to cover fully the whole of a two-year course, especially in such a wide-ranging subject as Computing. The contents of this text do, however, address most of the major topics common to the several syllabuses of the various examining boards. In addition, a number of subsidiary topics are included; the selection and the depth of coverage of each reflects the author's view of how the subject should be taught. This book is not intended, though, to constrain the teacher, who will undoubtedly wish to amplify certain topics and introduce further examples from his or her own experience. A Bibliography of other source material is included to provide additional background reading for instructors.

The defining occurrence of each important technical term is indicated by the use of bold typeface; as well as highlighting the defining context, this will enable rapid identification of key terms for revision purposes. Less significant technical words are indicated in italics, which are also used for occurrences of technical terms before they have been defined.

Within each chapter there is to be found a number of exercises, to be worked as they are encountered. These exercises are mostly designed to give practice in newly taught techniques; consequently, the frequency of their appearance is not uniform throughout the book. Solutions to these exercises are given at the end of the chapter. It must be emphasised that the solutions offered are usually not unique. Particularly in the case of programming exercises, there may be many equally valid alternatives. In certain chapters there are activities for the reader. These are either 
exercises of an extended nature, or practical activities to gather information in a particular context. Instructors may wish to select such activities as are suitable for their pupils. Further exercises are included at the end of each chapter; many of these have been taken from recent A-level papers.

The teaching material is in no way tied to a specific computer, and is usable in conjunction with any hardware. In those cases where it is necessary to illustrate a point with a program fragment, this is usually done in BBC BASIC, which is accessible to most educational institutions. An appendix provides the conversion to RM BASIC for other schools and colleges. Where necessary, programming features are illustrated in Pascal. Any serious student of programming will have to learn a language like Pascal, in the long term, in order to implement the design philosophy which this book sets out to teach. 


\section{Acknowledgements}

A number of people have been most helpful to me in the writing and production of this book. I should particularly like to place on record my thanks to Professor Manny Lehman of Imperial College, London, and Professor Frank Sumner of the University of Manchester for advice on the content of the book and for their comments on the drafts. I hope that no errors remain, but if any do the responsibility for them remains my own. I should also like to thank Doreen Tucker of the Faculty of Mathematics Word Processing Unit at the Open University for assistance in typing various drafts of the manuscript, and Malcolm Stewart of Macmillan Education for constant encouragement in seeing this book through.

My most special thanks go to my wife Judith, and to my children who are waiting eagerly to see this text in print, having so frequently heard that 'Daddy is busy on his book'.

Acknowledgement for the use of copyright material is hereby made to the Civil Aviation Authority (figures 5.7 and 10.9), AGFA-Gevaert Ltd (figure 5.17), Southdown Bus Company (figure 7.1), ICL (figures 11.5 and 11.7), Halifax Building Society (figure 11.6) and Sun Microsystems UK Ltd (figure 12.1). Questions from past examination papers are acknowledged individually to source. They are reproduced by permission of the Associated Examining Board, Joint Matriculation Board, University of Cambridge Local Examinations Syndicate and University of London Schools Examination Board. 